\title{
Idéer om arbetslöshet och social politik vid 1800 -talets mitt
}

JONAS OLOFSSON

När hamnade arbetslöshetsfrågan på den politiska dagordningen för första gången och hur motiverades de första arbetslöshetspolitiska ansatserna? Under 1800-talets snabba sociala och ekonomiska omvandling började arbetslöshet att framstå som ett socialt hot, och hjälpåtgärder riktade till arbetslösa som en angelägen socialpolitisk uppgift. Detta hängde i sin tur samman med politisk a förändringar vid 1800-talets mitt och avspeglade en snabb omvandling av det svenska samhällets grundstruktur. Framväxten av oreglerade marknader och sociala grupper som var beroende av lönearbete för sin försörjning bidrog till att det uppstod en arbetslöshetsfräga i modern mening.

Arbetslöshet är inte ett exklusivt fenomen för industrisamhället. ${ }^{1}$ Orsakerna till arbetslöshet har förändrats, men den gemensamma nämnaren har varit de begränsade

Jonas Olofsson är verksam som forskare vid ekonomisk-historiska institutionen vid Lunds universitet och som ekonom vid Vänsterpartiets riksdagskansli. I januari i år disputerade han på en avhandling om äldre arbetslöshetspolitik: "Arbetslöshetsfrågan i historisk belysning. En diskussion om arbetslöshet och social politik i Sverige 1830-1920“. Olofssons forskning har i huvudsak varit inriktad på "den svenska modellen", dess framväxt och sentida problem möjligheterna att erhålla avlönat arbete. Missväxt och brist på alternativa sysselsättningsmöjligheter under vintersäsongen förklarade en stor del av det förindustriella

1 Första gången begreppet arbetslöshet användes i offentligt material var i den fattigvårdsutredning som publicerades 1871 (1869 års fattigvårdskommitté). Tidigare talade man oftast om försvarslösa/lösdrivare, sysslolösa, vagabonder, näringslösa eller arbetsföra utan arbetsförtjänst för att beskriva arbetslösa eller fenomenet arbetslöshet. I artiklar och pamfletter återfinns uttrycket arbetslösa dock långt 
samhällets arbetslöshetsproblem. Men genom befolkningstillväxten och de sociala och ekonomiska förändringarna från slutet av 1700-talet och 1800-talets första hälft, blev arbetslöshetshotet i samtidens ögon mera påtagligt än tidigare. Befolkningstillväxten bidrog tillsammans med jordbruksomvandlingen till tillväxten av ett nytt slags jordbruksarbetare. De var inte som tidigare bundna till husbonden som tjänstehjon. De hade inte heller egna små jordbitar att falla tillbaka på vid nödtider. De levde uteslutande på att sälja sin arbetskraft och kunde därmed drabbas av försörjningssvårigheter under ekonomiskt svaga år. ${ }^{2}$

tidigare. Den enda författare som - förutom Hans Wallentin - har specialintresserat sig för arbetslöshetspolitikens förhistoria är Elfred

Kumm. Hans bok „Nödårsbygd och samhällshjälp" publicerades 1940 och får ses som ett viktigt bidrag till den intressanta bondehistorikertradition, som även innefattar namn som Alfred Kämpe och Vilhelm Moberg. I äldre ekonomisk-historisk forskning - och då framför allt i arbeten av Arthur Montgomery och Gustaf Utterström - uppmärksammades mer eller mindre i förbigående de diskussioner om arbetslöshet och de arbetslöshetspolitiska ansatser som utvecklades under 1800-talet.

Montgomery avfärdade i princip de medel som utvecklades som betydelselösa - utan att han undersökte de insatser som faktiskt gjordes närmare - och Utterström var alldeles för flyktig i sin behandling av arbetslöshetsfrågan, även om han å andra sidan hade undersökt betydligt mer källmaterial.

2 Denna problemuppfattning behöver inte strida mot den allmänna karakteristik forskningen $i$ dag ger perioden. Den agrara omvandlingen och ekonomiska tillväxten medförde både ökade och mer permanenta sysselsättningsmöjligheter för underklasserna. Samtidigt blev den individuella sårbarheten större.
Synen på den sociala politiken under 1800-talet har förändrats. I äldre forskning framhölls i allmänhet de partriarkala och förtryckande inslagen. Politikens främsta syfte var att kontrollera underklasserna och upprätthålla den rådande sociala ordningen. Denna syn genomsyrade bl.a. Arthur Montgomerys klassiska arbete om 1800-talets socialpolitik. ${ }^{3}$ I forskningen under de senaste 30 åren har perspektiven vidgats något. I Göran B. Nilssons efterföljd har politikens samhällsekonomiska samband och effekter framhävts. ${ }^{4}$ Intresset för förbindelselänkarna mellan institutionell och ekonomisk utveckling, fattigvårdslagstiftning och arbetsmarknad, samt socialpolitik och demografisk förändring, har allt mer kommit i centrum för forskningsintresset. ${ }^{5}$

I den här artikeln kommer jag att behandla framväxten av arbetslöshetsfrågan under decennierna strax före 1800-talets mitt. 1830- och 1840-talens debatter är inte bara intressanta därför att arbetslöshetsfrågan -i modern mening - uppstod. Diskussionerna och de politiska besluten illustrerade också behovet av politiska insatser för att balansera och motverka de ökade samhällsklyftor som följer under perioder med intensiv ekonomisk omvandling. För första gången motiverades offentliga insatser för att lindra och förebygga fattigdom inom ramen för en politik vars övergripande syfte var ekonomisk utveckling och sociala framsteg på marknadsekonomisk grund.

3 A. Montgomery, 1934.

4 G. B. Nilsson, 1965.

5 Diskussionen handlar inte bara den svenska fattigvårdslagstiftningen. Se t.ex.S. King, 1997, samt P. M. Solar, 1997. 


\section{Idédebatten om arbetslöshet och fattigdom vid 1800-talets mitt}

De ekonomiska och sociala förändringarna vid 1800-talets mitt präglade idédebatten och politiken genom att nya frågor och nya problem lyftes fram. Den snabba sociala differentieringen och det ökade arbetsmarknadsberoendet ruckade det gamla samhällets statiska syn på sociala frågor och tvingade fram mer dynamiska perspektiv. Äldre arbetsmarknadsregleringar kom i konflikt med den nya marknadsinriktade ekonomins villkor. Den kommunala institutionen utvecklades för att möta en ny tids behov av organiserad fattigvård och utbildning. Idédebatten i sociala frågor återspeglade de nya villkoren. Debatten handlade i stor utsträckning om vilken roll stat och kommuner skulle spela för att garantera stabilitet i samhället utan att den ekonomiska utvecklingen kvävdes av nya regleringar och förordningar. Idédebatten påverkades också av utländska influenser. Den engelska debatten om befolkningsfrågor och fattigvård samt kontinentala senmerkantilistiska och socialistiska idéer hade påtagligt inflytande på den svenska diskussionen.

Det fanns två huvudlinjer i debatten om fattigdom och arbetslöshet; en liberal och en socialkonservativ. De ideologiska och politiska utgångspunkterna för dessa båda huvudlinjer bestämde i sin tur synen på statligt initierade allmänna arbeten, på lokala nödhjälpsarbeten och statens roll i ekonomin. Synen på statens betydelse för att utveckla ekonomin och motverka sociala missförhållanden utgjorde den avgörande skilje- linjen i diskussionerna om fattigdom och arbetslöshet. ${ }^{6}$ Liberalerna poängterade betydelsen av det ekonomiska och sociala livets frihet från statlig styrning. De socialkonservativa och socialistiska grupperingarna framhöll istället behovet av statlig och politisk styrning för att garantera social stabilitet och en långsiktigt hållbar ekonomisk utveckling.

Även om samhällsdebatten i ekonomiska och sociala frågor blev allt mindre märkt av religiösa föreställningar, var den kristna etiken en viktig identitetsskapande faktor. I en bok från 1847 som presenterades tidens socialistiska tänkande - internationellt och nationellt - diskuterades religionens betydelse för synen på sociala relationer. Religionen och lagarna sågs som två sidor av samma mynt. Författaren, Carl Wilhelm Bergman (1820-57 $)^{7}$, menade att lagarna var till för att skydda den delen av befolkningen som hade stora egendomar från dem som inget ägde, medan religionen " deremot, såsom den allmännast tydes och tillämpas, är till för att trösta arbetaren deröfer, att han intet har och intet kan få. Vaka, arbeta och bed: se där religionens bud för den fattige; lid

6 I sentida forskning om socialpolitisk historia framställs ofta betoningen på statens ansvar för enskilda människors välbefinnande och försörjning som ett nytt inslag i den politiska debatt som utvecklades på 1880-talet, inte minst efter Adolf Hedins initiativ i arbetarförsäkringsfrågan. Jag menar således att detta är en felaktig uppfattning. Se t.ex. Anders Berge, 1995.

7 Carl Wilhelm Bergman var författare och historiker. Han skrev flitigt i den socialistiska tidskriften Reform och var en varm beundrare av Carl Jonas Love Almqvist. 
brist, försaka och tro Gud om godt: han hjälper dig nog; sker det ej här i lifvet, så sker det i ett tillkommande.$^{8}$ Alla accepterade inte heller situationen. Från 1840-talet blev lokala folkliga resningar, strejker och hungerupplopp allt vanligare. Orsakerna till dessa var skiftande - men livsmedelsbristen och de höga priserna på spannmål och potatis var oftast en starkt bidragande orsak. ${ }^{9}$

\section{Nya idéer om fattigdom och arbetslöshet}

I debatten om sociala frågor diskuterades således inte bara fattigvårdens omfattning och inriktning utan man försökte också fånga orsakerna till fattigdomen. Detta var något kvalitativt nytt. Tidigare hade fattigdomen tagits för given. Diskuterades någon gång orsakerna så framhölls huvudsakligen individuella karakteristika, sjukdom, handikapp, ålderdom, lättja eller ovilja att arbeta. $\mathrm{Nu}$ togs ytterligare ett steg. Det man uppfattade som en allt mer utbredd "pauperism" i samhället togs till intäkt för att fattigdomen kunde ha strukturella och samhälleliga orsaker, t.ex. jordbrukets bristfälliga utvecklingsnivå och sociala missförhållanden. ${ }^{10}$ Detta var en ny förståelse av fattigdomen i samhället som ibland tillskrivits den

8 C. W. Bergman, 1848, s. VIII.

9 Dessa folkliga resningar är skildrade i Rolf Karlboms studie om hungerupplopp och strejker. Se R. Karlbom, 1967.

10 I flera publikationer betonades att jordbrukets ensidiga inriktning på spannmålsproduktion var den avgörande orsaken till de ständigt återkommande missväxt- och produktionsproblemen. Majoren Carl Theodor af Ekenstam framhöll i en artikel från 1847 att en positiv utveckling av jordbruket förutsatte växelbruk och en ökad animalieproduktion. Se senmerkantilistiska traditionen. Men det fanns också en begynnande socialistisk förståelse av fattigdomens orsaker. Enligt Bergman berodde den "nya" fattigdomen på den särskilda ställning marbetet intagit till kapitalet", att arbetet bara "uppskattades som en död sakı och att dess avkastning bestämdes av helt "mekaniska lagar». Bergman menade vidare att arbetskraften "utbytas till penningevinst för en särskild klass i samhället, och alltsom denne sednares intresse fordrar tagas i anspråk, eller öfverlämnas skoningslöst åt förhungrandet" ${ }^{11}$

Bergman insåg visserligen att den industriella utvecklingen inte var särskilt långt gången i Sverige, men menade ändå att tesen om en huvudmotsättning mellan arbete och kapital var giltig genom utvecklingen av de nya driftsformerna och lönearbetsrelationerna inom jordbruket. Motsvarande uppfattning om de "moderna" lönearbetarrelationernas fördärvliga inflytande på de sociala villkoren i landet framfördes också av mer socialkonservativa politiker som Carl Adolph Agardh och godsherren och riksdagsmannen Carl Raab, den senare i en kritisk skrift om "Statkarls-systemet i Sverige» från 1847. Men den nostalgi kring de gamla husbonderelationerna som odlades i konser-

t.ex. C. Ekenstam, 1847, s. 87. De svåra missväxterna under 1860-talets slut föranledde också en rad diskussioner om jordbrukets problem. Flera av dessa diskussionsinlägg hade en mycket tydlig politisk udd. Åtskilliga godsägare besvärades av att spannmålstullarna togs bort på 1850-talet och av de statliga investeringarna i allmänna arbeten, som påstods öka konkurrensen om arbetskraft och höja lönenivåerna. Se t.ex. R.M. Klickowström, 1867.

11 C. W. Bergman, 1848, s. 1. 
vativa kretsar tilltalade knappast socialister som Bergman.

\section{Geijer och det malthusianska idéinflytandet}

Erik Gustaf Geijer (1783-1847) var en av de mer framträdande förespråkarna för en konservativ politik under 1820-talet och första hälften av 1830-talet. Han var påtagligt inspirerad av Malthus arbeten. Malthus skrifter $i$ befolkningsfrågan fick genomslag $i$ Sverige när synen på befolkningsutvecklingen skiftade i mer negativ riktning något eller ett par decennier in på 1800-talet. ${ }^{12}$ Det var de obesuttna och underklassernas våldsamma tillväxt som tilldrog sig intresset.

Det är speciellt intressant att studera Geijers inlägg under denna period i perspektivet av hans omsvängning i liberal riktning under slutet av 1830-talet. Geijer tillhörde till en början dem som förespråkade en tjänstehjonslagstiftning efter gamla linjer. Tillväxten av underklasserna, den ökade pauperiseringen och ett påstått ökat

12 Malthus befolkningsdoktrin fick stort inflytande i den svenska debatten, men det var ingalunda frågan om någon odelad beundran. Åtskilliga debattörer markerade distans. I de radikala politiska leden på vänsterkanten väckte han mycket stark aversion, inte minst hos Bergman. Apropå den engelska fattiglagen från $1834 \mathrm{skrev}$ Bergman: „Denna lag hvilar på den malthusianska åsigten om fattigdomen såsom ett brott hvilket likt andra brott förtjenar sitt straff. Den grymma inrättningen af de enligt densamma uppförda arbetshusen är också så stor, att de arbetslöse hellre förhungrat, än genom inträdandet i desamma tagit del i det offentliga understödetw. C. W. Bergman, 1848, s. 5. fattigvårdsbehov, härleddes ur den upplösning av den restriktiva agrarpolitiken, som tagit sin början vid mitten och andra hälften av 1700-talet under inverkan av de dåtida befolkningsteoretiska doktrinerna. Geijer menade alltså att problemen skulle förvärras ytterligare genom de nya lagarna från 1827 , bl.a. om laga skifte. Geijer hävdade i stället betydelsen av en återgång till mera restriktiva linjer, och denna grundinställning präglade hans uppfattning om försvarslöshetssystemet. Han kritiserade skarpt de korrektionsinrättningar som inrättats för försvarslösa under tidigt 1800-tal: „Må man då i någon mon återkomma från denna förplägnad af vanarten, som gör den till ett skötebarn på bekostnad af samhällets välstånd och hälsa, från denna falska mildhet som i sig sjelf är omild och mot ett ständigt och vådligt tillväxande ont snart skall påfordra en ytterlig stränghet hvilken man kunnat undvikau. ${ }^{13}$

Alf Kjellén, som skrivit om utvecklingen av Geijers ekonomisk-politiska tänkande, menade att åtskilliga konservativa hämtade argument från Malthus och det brittiska whigpartiet $\mathrm{i}$ fattigvårdsfrågan. Det motsägelsefulla var alltså att de utnyttjade ekonomisk-liberala argument i befolkningsfrågan för att befrämja en politik som annars inte hade mycket med liberalism att göra. De motsatte sig avregleringar och förespråkade i stället en starkare statlig styrning. I arbetskraftspolitiken, agrarpolitiken och fattigvårdsfrågan blev denna paradox särskilt tydlig. Med sociala utgångspunkter ifrågasatte man jordbruksomvandlingen på grund av tillväxten av underklasserna i all-

13 Citerat efter A. Kjellén, 1933, s. 294-295. 
mänhet och - kanske för Geijers del i synnerhet - på grund av den nya statarklassen vid storjordbruken. Dessa grupper stod utanför den gamla tjänstehjonsstadgan. Idealet var den gamla husbonderelationen, med förordningar om ömsesidigt ansvar och ömsesidiga skyldigheter, som den tog sig uttryck i tjänstehjonsstadgan och i hantverksoch skrålagstiftningen samt i regleringarna kring bergsbrukens verksamhet.

Att Malthus kom att utnyttjas i argumentationen för denna politik är ironiskt om än typiskt. När det gällde agrarpolitiken och Malthus uppfattning om denna, så visar inte minst hans egen skrift från resan i Sverige, att han långt ifrån delade Geijers uppfattning. Han konstaterade där att de svenska bönderna nu hade rätt att klyva sina ägor $i$ hur många delar som helst och menade vidare, att med "tanke på de svenska hemmanens väldiga arealer och det faktum att en enda familj omöjligen ensam kan odla upp dessa väldiga vidder, måste dessa ägodelningar ur alla synpunkter betraktas som högst nyttigar. ${ }^{14}$

\section{Geijers "avfall"}

Geijer utnyttjade malthusianska argument under 1820- och 1830-talen för en mer restriktiv linje $\mathrm{i}$ fattigvårds- och arbetskraftspolitiken, men med helt andra utgångspunkter än Malthus. Åren 1838 och 1839 skulle han återkomma till fattigvårdsfrågan och befolkningsfrågan, men nu med en annan och mer liberal grundsyn. Paradoxalt nog - och typiskt för svensk samtida debatt - frigjorde han sig mer och mer från Malthus befolkningsteorier samtidigt som han

14 G. Borgström, 1969, s. 159. successivt tillägnade sig en ekonomisk-liberal samhällsuppfattning. Det var i en serie artiklar i Litteratur-bladet år 1839 han skulle ta upp pauperiseringsproblemet till förnyad debatt.

Geijer hade nu lämnat sin tidigare antikommersiella och antiindustriella grundsyn. Han menade att överbefolkningens problem, som Malthus skildrat, var verkliga, men att dessa kunde hänföras till det jordbruksdominerade samhället. Vidare hävdade han att det fanns flera gångbara perspektiv på överbefolkningsproblemet. Det behövde med andra ord inte enbart vara av ondo: „Människan är ej ett så lättlärt barn, att hon att hon ej skulle behöva nöden som läromästare«.$^{15}$ Nöden kunde alltså fungera som en välbehövlig piska - ett tema som Geijer också tog upp vid 1840-41 års riksdag i en debatt med Carl Adolph Agardh. Det var agrardominansen som skapade de problem som sammanhängde med överbefolkningen. ${ }^{16}$ Lösningen såg han $i$ att utveckla, vad han kallade, „flera näringsfångu.

«Maskinindustrin" var framtidens melodi och skulle överbrygga den malthusianska befolkningslagen. Geijer betonade därför att allt hantverksmässigt och proletärt motstånd mot de nya fabrikerna, som var så vanligt i England, i grunden var fruktlöst. Industriernas överlägsenhet bottnade främst, enligt Geijer, i att »de föda flera». ${ }^{17}$ Nyckeln

15 J. Landquist, 1928, s. 420.

16 „En blott jorbrukande folkmängd, och (vilket i slikt fall merendels händer) delande sin jord $i$ nästan oändlighet, kommer just, i följe av sitt fasthängande vid jorden, snart till en överbefolkning, som blir pöbel, och en föga mindre fruktansvärd än manufakturpöbeln«. J. Landquist, 1928, s. 423-424. 
var "maskinindustrins" höga produktivitet. Även om dagslönerna föll så kompenserades detta av att produktionskvantiteten steg $\mathrm{i}$ en sådan omfattning, att prisfallet mer än väl kompenserade fallet i de nominella lönerna.

Geijer menade att överbefolkningsproblemet var en realitet. Detta berodde på att den nya typen av arbetsavtal och daglönesystem expanderat utan att någon industriell produktion utvecklats i Sverige. Inom agrarsamhällets ram skulle dessa problem aldrig kunna lösas. Han tillskrev inte längre den gamla arbetskraftspolitiken, tjänstehjonsstadgans regleringar och försvarslöshetssystemet, någon positiv betydelse i detta sammanhang. Tvärtom var dessa lagar och regleringar ett hinder för utvecklingen under de nya förhållandena: "Nya, billigare, bestämmelser äro i synnerhet nödiga i den gamla, hårda lagstiftningen om laga försvar, både $i$ avseende på de försvarslöse, vilka icke äro brottslingar, och $\mathrm{i}$ avseende på dem, som blivit det, men utstått sitt straffu. ${ }^{18}$ När det gällde mer positiva förslag om fattigvårdspolitiken anknöt han därför till kommittébetänkandet, som utkom samma år som hans artiklar i fattigvårdsfrågan. Samhället var förpliktigat att erbjuda undsättning till barn, ålderstigna och "lame, lytte, sjuke, sinnesvage med flera av samma olycksslagu..$^{19}$ Geijer ifrågasatte aldrig behovet av hjälpinsatser för dessa kategorier.

17 J. Landquist, 1928, s. 426.

18 J. Landquist, 1928, s. 518.

19 J. Landquist, 1928, s. 512.

\section{Det senmerkantilistiska idéinflytandet}

De malthusianska och liberala idéerna motarbetades av socialkonservativt orienterade politiker och debattörer som var inspirerade av den senmerkantilistiska traditionen. Den senmerkantilistiska idéutvecklingen förde med sig en radikalt ny syn på sociala frågor. Nu hävdades det att samhället - av såväl befolkningsmässiga som samhällsekonomiska skäl - skulle vara betjänt av att bättre värna de sämst ställda gruppernas intressen. ${ }^{20}$ I praktiken medförde detta att de fattiga kategoriserades på ett nytt sätt. Till gruppen av traditionellt fattigvårds- och understödsberättigade fördes nu vuxna arbetsföra som inte lyckats skaffa sig arbete och försörjning på egen hand. Ett väsentligt inslag i den senmerkantilistiska politiken var att arbetslösa inte skulle sättas i straffarbete, som i den äldre merkantilistiska doktrinen, utan särskilda nödhjälpsarbeten skulle skapas för de ofrivilligt arbetslösa. I flera länder i Europa slog dessa tankar igenom i den sociala lagstiftningen från sent 1700-tal, bl.a. i England där "An Act for the Better Relief and Employment of the Poor" antogs år 1782. I denna lag erkändes samhällets skyldighet att skapa arbetstillfällen för de ofrivilligt arbetslösa. I lagtexten hette det att det var samhällets plikt att skaffa de arbetslösa arbete, "suited to his or her strength and capacity, in any parish or place near the place of his or her residence, and to mantain, or cause such person or persons to be properly maintained, lodged, and provi-

20 Om senmerkantilismens inflytande på socialpolitiken, se t.ex. H. C. Johansen, 1968, s. 264276 samt A.-L. Seip, 1984, s. 28-30. 
ded for, until such employment shall be procured «. ${ }^{21}$ Dessutom stadgades, att lönerna för dessa nödhjälpsarbeten skulle vara tillräckligt höga var för att garantera de arbetslösas försörjning.

De nya idéerna vann förankring i flera länder i Europa. I såväl Frankrike - 1789 som i Tyskland uttalades tankar om att samhället inte längre borde bestraffa de arbetslösa utan erbjuda understöd i form av arbete. En ofta omnämnd senmerkantilistisk tänkare var tysken Johan Georg Büsch. Büsch kom att utveckla en omdiskuterad social hjälpverksamhet i Hamburg under 1700-talets sista decennier. Hjälpverksamheten fick en mycket ambitiös inriktning. Hälsovård och medicin erbjöds utan kostnader. Sjukdomsunderstöd utbetalades. När det gällde frågor om omhändertagande av barn försökte man in i det längsta att undvika institutionsformen. På dagarna skulle emellertid barnen lämnas på »institution " så att kvinnoras arbetskraft kunde utnyttjas på arbetsmarknaden. Man experimenterade också med bostadsstöd och ekonomiskt stöd till uppvärmning. Föräldrar som lämnade sina barn i skola fick särskilt understöd. ${ }^{22}$ Understöd utlämnades dock enbart efter noggranna behovsprövningar.

Hela detta hjälpprogram underbyggde Büsch med sin ekonomisk-politiska doktrin. Büsch föreslog i första hand en mer expansiv penningpolitik. Cirkulationen av mynt och sedlar skulle öka - upp till en viss nivå vilket i sin tur skulle stimulera investeringar och sysselsättning. Detta blev också ett starkt argument för att fattiga skulle erbju-

21 Citerat efter H. C. Johansen, 1968, s. 264.

22 A.-L. Seip, 1984, s. 30-32. das hjälp i form av pengar och avlönat arbete. Hela ekonomin skulle stimuleras av att fler kom i sysselsättning och av att efterfrågan på konsumtionsvaror ökade. Som den norske historikern Anne-Lise Seip betonat såg inte Büsch nödhjälpsarbeten ur privatekonomisk synpunkt, utan snarare som ett sätt att stimulera hela samhällsekonomin. ${ }^{23}$ Detta var uppfattningar som senare återkom i svensk debatt.

\section{En "rehabilitering" av de fattiga}

Flera forskare har hävdat att det sena 1700talet och tidiga 1800-talet medförde en brytning med den tidigmoderna tidens stränga behandling av fattiga och arbetslösa. På 1600-talet ville man avskilja och avsöndra de fattiga. De skulle osynliggöras och interneringen och bestraffningen i fängelseliknande anstalter blev det främsta uttrycket för denna politik. Men samhällsförändringarna, och framför allt effekterna av ett mer kommersiellt inriktat jordbruk, bidrog till att fattigdomen och arbetslösheten började uppfattas på ett nytt sätt. Michel Foucault menade att det inte längre gick att skylla arbetslösheten på individernas lättja: "man har sett armodet och den påtvingade sysslolösheten sprida sig genom landsbygden där man hade trott sig kunna möta det moraliska livets mest omdelbara och och renaste former; allt detta har avslöjat att misären måhända inte endast kommer av dåliga egenskaper ${ }^{24}$ I grunden var det fråga om en "moralisk rehabilitering" av de fattiga som hade sitt ursprung i ekonomiska förhållanden, d.v.s. i nödvändigheten att skapa en

24 M. Foucault, 1986, s. 246-247. 
bredare och rörligare arbetsmarknad för att möta det kommersiellt inriktade jordbrukets och den uppspirande industrins arbetskraftsbehov. Detta var den ekonomiska bakgrunden till det nya socialpolitiska tänkandet under den senmerkantilistiska perioden. Den äldre merkantilistiska politiken att avskilja de fattiga och arbetslösa från samhället i övrigt blev direkt irrationell i den nya ekonomiska miljö som växte fram från slutet av 1700-talet och början av 1800talet.

Alla dessa nya uppfattningar spred sig också till den svenska diskussionen. Det mer humanitära draget avspeglade sig bl.a. i Chydenius skrifter från slutet av 1700-talet. Men de fanns också med i 1810 års fattigvårdskommittés betänkande från 1823 . I detta betänkande talades det om arbetslöshet som en legitim orsak till fattigdom. Men betänkandet antogs inte av riksdagen. Först i och med 1837 års fattigvårdskommittés betänkande och den debatt som därefter följde på 1840-talet, skulle de nya uppfattningarna i sociala frågor komma mera fritt till uttryck.

\section{7 års fattigvårdskommitté om orsakerna till fattigdomen}

1837 års fattigvårdskommitté höll sitt första möte i januari 1839 och levererade betänkandet efter sitt sista möte i juni 1839.25 Sammanlagt hölls under detta knappa halvår sextiosex möten. Arton personer ingick i kommittén och undertecknade det slutgil-

25 Handlingar från 1837 års fattigvårdskommitté. Riksarkivet. Kommittébetänkandet offentliggjordes i oktober 1839 och trycktes i 1300 exemplar. tiga betänkandet. Ordförande i kommittén var den tidigare presidenten i Göta hovrätt Abraham Leijonhufvud (1785-1843) ${ }^{26}$ De övriga ledamöterna utgjorde en blandad skara av politiker, präster och statstjänstemän. Ledamöterna hade stora svårigheter att komma överens politiskt. Men kommitténs arbete blev ändå mycket betydelsefullt. Det var den första riktigt omfattande utredningen om den sociala och ekonomiska utvecklingen i Sverige. Knappast någon fråga av större vikt lämnades utanför kommitténs intressefält. Utredningen fick därför konsekvenser på en rad andra områden utanför den rena fattigvårdspolitiken.

Ordföranden Leijonhufvud skrev ett underlag för kommitténs arbete där han försökte jämka de olika uppfattningarna. ${ }^{27}$ Kommittén hade tre huvuduppgifter. För det första skulle kommittén analysera fattigdomens orsaker. För det andra skulle man reda ut fattigdomens följder. Slutligen, för det tredje, skulle man behandla vad Leijonhufvud kallade ifattigdomens utrotander. Med den sistnämnda uppgiften avsågs försörjning av de "verkligt behövande», att skaffa arbete åt sysslolösa och »att genom klok fattigvård förminska armodet, dess tillväxt och dess inflytelser. Leijonhufvud avslöjade sin egen tidstypiska inställning till fattigvårdsfrågan när han underströk det stora ansvar och de stora förväntningar som fanns

26 Leijonhufvud som gjorde en framgångsrik ämbetsmannakarriär har emellertid blivit mest omtalad för sina skildringar av studentlivet i Lund i början av 1800-talet och för sina anteckningar om Esias Tegnér som under några år var hans informator.

27 Handlingar från 1837 års fattigvårdskommitté. Leijonhufvuds PM. Riksarkivet. 
på kommitténs arbete. För vanliga människor var det nämligen en "förödmjukelse att omgifvas af en talrik Samhällsklass, som går höljd i trasor, som hvarken arbetar eller gagnar, men istället tigger om dagen, och föröfvar, under nattens mörker, alla de oordningar eller brott hvartill ett stigande sederförderf uppmuntrar".

Vad ansåg man då i fattigvårdskommittén om fattigdomens orsaker? I betänkandet talade man om "enskilda" och "allmänna" orsaker till fattigdomen. Med enskilda avsågs naturligtvis individuella orsaker och med allmänna samhällelliga eller sociala orsaker. På mötena behandlades orsakerna till fattigdomen punktvis. Behandlingen gick trögt eftersom meningarna oftast var delade. Leijonhufvud sammanfattade kommitténs diskussioner om fattigdomens orsaker i fem punkter:

1) Handikappade, sinnessjuka, barn och gamla som inte klarar att försörja sig själva.

2) Svaga och sjukliga personer som trots viss arbetsförmåga inte klarar att generera tillräckliga inkomster för sin egen och sin familjs försörjning.

3) Ofrivillig arbetslöshet.

4) Frivillig arbetslöshet (enligt Leijonhufvud de "Late - tröge - elakartade tiggande och de i sysslolöst sjelfsvåld omkring landet strykande $)$.

5) Tillfälliga orsaker till fattigdom: sjukdom, förlust av egendom och förlust av anhörig.

På viktiga områden var uppfattningarna i kommittén djupt splittrade. Det gällde inte minst i en så viktig fråga som näringsfrihets- frågan. Efter många och långa diskussioner kom kommittén fram till att inskränkningar i näringsfriheten inte skulle betrakats som en orsak till fattigdomen. ${ }^{28}$ Detta beslut väckte naturligtvis stark förbittring i det liberala lägret. Liberalerna kritiserade att "brist på rörelse-capital och enskild credit» inte heller togs upp som en betydande fattigdomsorsak. Dessutom var kommitténs splittrad i sin inställning till liberaliseringen av hemmansklyvning och jordavsöndring från 1827. Kommittén avvisade inte hela reformen men talade om "missbruk". Alltför omfattande anläggning av backstugor betraktades som en fattigdomsorsak. Däremot ville man inte generellt hävda att nybyggnadsanläggningar bidrog till fattigdomen i landet - annat än med "dermed åtföljande missbrukı. Samtliga dessa ställningstaganden avspeglade en viss övervikt för det konservativa lägret i fattigvårdskommittén.

Avslutningsvis framhöll Leijonhufvud huvudsyftet med fattigvårdens verksamhet. För hans egen del var det socialpreventiva motivet helt dominerande. Fattigvården kunde inte organiseras på någon annan grundval än att antalet fattiga blev större för varje dag, och ratt inflytelsen deraf fräter på Samhällets trefnad samt att detsammas bestånd möjligtvis kan äfventyras, om icke en kraftig hjelp uppställes emot ett olycksförhållande som under så mångväxlande former tilltagande utvecklas».

28 Fattigvårdskommitténs möte 18390207 . Däremot menade man alltså att näringsfrihet $-i$ vissa sammanhang - kunde bidra till fattigdomens utbredning. 


\section{Två huvudlinjer: liberaler och socialkonservativa om fattigdom och arbetslöshet}

Diskussionerna i 1837 års fattigvårdskommitté och det slutliga betänkandet återspeglade alltså kluvna uppfattningar i flera viktiga frågor. Det var också helt följdriktigt, eftersom mer liberala politiker, bl.a. bondeståndets företrädare Hans Jansson (17921854), skulle samsas med utpräglat konservativa representanter som t.ex. biskopen Christoffer Heurlin (1786-1860). ${ }^{29}$ Betänkandet var en utpräglad kompromissprodukt - och en ganska osmält sådan - trots att kommittén varit i verksamhet i ett halvår, vilket var en relativt utdragen tidsperiod för ett kommittéarbete under tidigt 1800 tal. De olika uppfattningar om - och hur samhället skulle hantera arbetslöshetsfrågan, som fanns i 1837 års fattigvårdskommitté, återkom sedan med i princip samma innehåll men i olika yttre utformning fram till 1900-talets början.

Varken i fattigvårdsfrågan eller i synen på arbetslösheten kan man säga att det

29 Hans Jansson var vid den här tiden den ledande liberala kraften inom bondeståndet; känd för sin starka opposition mot Karl Johans regim och sitt arbete för sparsamhet med statens medel, skattelindringar för fattigt folk och för en utbyggd folkundervisning. En intressant händelse i fattigvårdskommitténs arbete, som $\mathrm{i}$ någon mån avspeglar villkoren för den tidens bondepolitiker, var de finansieringsproblem som ständigt präglade Janssons Stockholmsresor. Han hade tydligen inga möjligheter att själv täcka resekostnaderna och uteblev av den anledningen från flera möten. Kommittén fick därför lägga in speciella äskanden för att slutligen finna en lösning på problemet. fanns några entydiga politiska eller ideologiska formationer, jämförbara med positionerna i näringsfrihetsfrågan. När vi talar om en »liberal " och en "socialkonservativ" gruppering gör vi därför lätt våld på verkligheten. Men det går att se två övergripande huvudlinjer i sociala frågor. Båda huvudlinjerna hängde också intimt samman med två skilda ekonomisk-politiska doktriner.

Den liberala och harmoniekonomiska samhällssynen fick ökat stöd under 1800talets första hälft. Adam Smith och J. B. Say blev föremål för livliga studier i Sverige. Gripenstedt besökte den franska nationalförsamlingen och inspirerades av debatterna $\mathrm{i}$ ekonomifrågor under en vistelse $\mathrm{i}$ Frankrike på 1840-talet. ${ }^{30}$ Vid mitten av 1800-talet blev också den franske militante frihandelsförespråkaren Frédéric Bastiat allt mer populär tillsammans med en hel rad andra - ofta franska - liberala ekonomer. ${ }^{31}$

De liberala samhällsdebattörerna i Sverige utgjorde ingen homogen grupp. Där fanns pragmatiskt inriktade såväl som mer militanta krafter. I synen på sociala frågor var också spännvidden stor. Ett exempel på den mer restriktiva och kärva synen i fattigvårdsfrågan utgörs av prästen och missionären Petrus Lestadius (1802-1842) skrift "Tankar om fattigdomen och fattigvården $\mathrm{i}$ Sverige« från 1840. Denna debattskrift var en direkt reaktion på fattigvårdsbetänkandet från 1839. Lestadius poängterade att omsorgen om de fattiga först och främst var

30 S. O. Gasslander, 1949, s. 118-121.

31 Gripenstedts stora beundran för Bastiat är omvittnad. Eli Heckscher hade emellertid inga varmare ord till övers för popularisatorer som Bastiat utan betraktade honom som "överskattad». Se t.ex. E. Heckscher, 1963, s. 306. 
en »kristlig» plikt. Den kunde aldrig - utan allvarliga moraliska och ekonomiska konsekvenser - förvandlas till en samhällelig eller borgerlig skyldighet. Det vore enligt Lestadius ett allvarligt misstag att inlåta sig på stadganden om de fattigas "rätt" till fattigvård och omsorg. Om fattigvårdsbetänkandets förslag omsattes i verkligheten skulle de fattiga förvandlas till ufordringsegare, en pockande exactor af sina rättigheter ${ }^{32}$ Konsekvenserna skulle bli absurda. Lestadius menade i manchesterliberal anda att varje individ i första hand var skyldig att försörja sig själv, och därmed också borde få använda sin arbetskraft på vilket sätt som helst, under förutsättning att ingen annan kom till skada. ${ }^{33}$

En annan och mindre restriktiv liberal än Lestadius var den ovan omnämnde juristen Olof Johan Hultgren. I ett arbete från 1855 diskuterade han den "nyau fattigdomens uttryck och orsaker. ${ }^{34}$ Enligt Hultgren erkändes allmänt fattigdomen som en av "vår tids svåraste samhällslidanden" som hotade "sjelfva grundvalarnau för samhället. ${ }^{35}$ Pauperismen var enligt författaren det normala tillstånd som en "särskild klass" i samhället alltid befann sig $i$ och wär en för den nyare tiden helt och hållet egendomlig företeelse». Precis som åtskilliga andra debattörer vid denna tid diskuterade inte heller Hultgren

32 P. Lestadius, 1840, s. 8.

33 Lestadius menade satt hvar och en må baka bröd och göra skor, bäst de gitta och kunna, att, med ett ord, hvar och en må försörja sig, bäst han gitter och kan, mot villkor att icke störa andra i deras lika lofliga bemödanden att försörja sigu. P. Lestadius, 1840, s. 6.

34 O. J. Hultgren, 1855.

35 O. J. Hultgren, 1855, s. 3. fattigdomens absoluta betydelse. Han uppfattade pauperismen som en social kategori - en följd av förändringarna i samhället. När det gällde orsakerna till den ökande fattigdomen hänvisade han framför allt till tillväxten av landsbygdsproletariatet i kombination med "felaktiga lagstiftningsåtgärder till inskränkning af näringshågens fria utveckling«. ${ }^{36}$

\section{Gripenstedt om fattigdom och arbetslöshet}

Den blivande finansministern Johan A. Gripenstedt (1813-74) var också en av dem som företrädde mer renodlade ekonomiskliberala uppfattningar i sociala frågor: Enligt honom var offentliga sociala inrättningar något onaturligt. Varje individ skulle försörja sig själv. Klarade han eller hon inte detta var det de anhöriga som i första hand skulle bära ansvaret. Samtidigt betonade han såväl den moraliska som sociala betydelsen av frivilliga välgörenhetsinrättningar. I ett anförande i riddarhuset 1840 menade Gripenstedt att den som ville öka omfattningen av de kommunala och statliga insatserna för fattigvård och undsättningsverksamhet, dvs. som en samhällelig skyldighet och inte som en "christlig plikt", var ute på farliga vägar. Resultatet kunde bli att såväl »kärleken" och "barmhärtigheten" på den givande sidan, som "ödmjukheten" och "tacksamheten" på den mottagande sidan, successivt upphörde. Viljan att hjälpa andra skulle därmed förvandlas till en "förbittrad pligt utan tillfredsställelse« och mottagandet av hiälp "till pockande rätt utan följsamhetu. ${ }^{37}$ Det

36 O. J. Hultgren, 1855, s. 6.

37 J. A. Gripenstedt, 1871, s. 59. 
var över huvud taget ett kännetecken för den liberala inställningen $i$ sociala frågor att man starkt framhöll den privata välgörenhetens betydelse, samt moraliska och ekonomiska överlägsenhet, jämfört med den offentliga understödsverksamheten. ${ }^{38}$

För mycket offentlig omsorg förslöade och demoraliserade människor. ${ }^{39}$ Offentliga åtgärder försvagade anpassningen till en naturlig och självreglerande arbetsmarknad. För omfattande och generös fattigförsörjning från statens och kommunernas sida var direkt förödande, blev en fattigdomsfälla och bidrog direkt till tillväxten av antalet fattiga i samhället. För att förhindra att gruppen understödsberoende fattiga fastnade i sitt tillstånd och växte i antal, menade man, att understödsverksamheten borde utformas på ett sådant sätt att de som inte var absolut behövande avskräcktes. Formerna för verksamheten blev i sig ett viktigt urvalsinstrument för att urskilja "verkligt« behövande från dem som i själva verket kunde klara sig på annat sätt. Det var den principen som låg till grund för fattigvårdsreformen i England 1834 - och kom att kallas

\section{A.-L. Seip, 1984.}

39 Denna uppfattning återkom sedan i den ekonomisk-liberala argumentatitionen. Som Anders Berge skriver i en uppsats om den socialpolitiska debatten vid 1800-talets slut, så gick den harmoniliberala grundsynen ut på att människor skulle försörja sig genom transaktioner på marknaden - genom utbyte av "likvärdiga ekvivalenter". Men även liberalerna tvingades erkänna att detta försörjningssystem inte var heltäckande. Det behövdes en politisk omfördelning av resurser för att tillgodose försörjningsbehovet hos grupper på marginalen. Men dessa politiska ingrepp skulle hållas vid ett minimum. Se A. Berge, 1995, s 69. "less eligibility" - och som gjorde intryck på åtskilliga svenska debattörer vid den här tiden.

I den engelska fattigvårdsreformen avskaffades all s.k. nout door-relief" och därmed också nödhjälpsarbeten som understödsform. Gripenstedt framhöll denna reform som ett föredöme, också mot dem som förespråkade mer omfattande satsningar på allmänna arbeten. Han menade att fattigdom och arbetslöshet oftast inte alls berodde på att sysselsättningstillfällen saknades, utan snarare på bristande arbetsvilja. ${ }^{40} \mathrm{Där}$ igenom skulle det också bli mycket svårt att få något meningsfullt och samhällsnyttigt arbete utfört. Gripenstedt frågade sig »om detta lösa arbetsfolk, som säkerligen till största delen skulle komma att bestå af lata och liderliga personer, ingenting vill göra, utan blott står och hänger öfver spaden, hvad skall då ske? «l $^{41}$ Problemet var enligt Gripenstedt, att om man i förordningar och stadgor bestämde att de fattiga hade rätt till understöd, eller att de arbetslösa hade rätt till arbete, skulle tillströmningen från »den jämrande och hycklande fattighopen" bli enorm och kostnaderna för samhället betungande. I likhet med Bastiats kritik av systemet med allmänna arbeten, menade han också, att skattefinansieringen av denna improduktiva och ineffektiva verksamhet snedvred resursfördelningen $i$ samhället och förhindrade en naturlig och harmonisk anpassning i ekonomin. ${ }^{42}$ Om arbetsmarknaden bara lämnades utan offentliga in-

40 J. A. Gripenstedt, 187.1, s. 63.

41 J. A. Gripenstedt, 1871, s. 60.

42 När det gäller Bastiats uppfattning om allmänna arbeten, se t.ex. F. Bastiat, 1954. 
grepp och regleringar, skulle människor tvingas anpassa sig till rådande utbuds- och efterfrågeförhållanden, och därmed skulle också arbetslösheten successivt försvinna.

Liberalernas uppfattning i sociala frågor stod i nära förbindelse med kraven på näringsfrihet. Under 1840-talets första hälft bedrevs en intensiv kampanj för utvidgad näringsfrihet som resulterade i näringsfrihetsreformen 1846. Samtidigt utpekades på konservativt håll näringsfriheten och den fria konkurrensen som några av de främsta orsakerna till att antalet fattiga och arbetslösa växte. Liberalerna menade att en friare ekonomi skulle kunna höja hela samhället till oanade materiella höjder - här fanns otvetydigt en stark framtidstro och utvecklingsoptimism. Konservativa och socialistiskt inspirerade debattörer hävdade tvärtom att näringsfriheten och den fria konkurrensen ökade spännvidden mellan olika grupper i samhället. Därigenom hotades också i förlängningen hela samhällets stabilitet. För åtskilliga konservativa handlade det förmodligen om ett romantiserande av ett förgånget samhälle och arbetsliv, det patriarkala husbondeväldet. För andra handlade det om en klarare insikt om att man befann sig i en brytningstid; att omvandlingen av jordbruk och industriell tillväxt var önskvärda förändringar, men att utvecklingen måste ges socialt acceptabla former.

\section{Lundell om näringsfrihet och arbetslöshet}

År 1846 presenterades en intressant avhandling i Lund om näringsfrihet och sociala villkor i en "friare« ekonomi av läraren i ekonomi och juridik, Jacob Lundell (1813-
52). ${ }^{43}$ Han inledde avhandlingen med att skärskåda invändningarna mot näringsfriheten. Kritikerna erkände enligt Lundell oftast det positiva inflytande som warbetets frihet" haft på "rikedomens och civilisationens« tillväxt, men de menade samtidigt att välståndet koncentrerats i ett fåtal händer. Orsakerna till detta var den hårda konkurrensen om arbetstillfällen. Företagarna kunde pressa lönerna till mycket låga nivåer och alltid ersätta arbetskraft med maskiner om arbetskraftskostnaderna hotade att bli för höga. Lundell konstaterade att arbetets »befrielse, hvarpå menskligheten i årtusenden arbetat, har således endast varit en olycka för sjelfva den arbetande klassen, och man fordrar nu att samhället skall göra ett slut på detta olycksaliga tillstånd och befria arbetaren från concurrensens vådor «. ${ }^{44}$

Lundell avsikt var emellertid att bemöta kritiken. I likhet med Geijer, som hävdade att fattigdomen var en nödvändig "piska" för att tvinga människor till aktiva arbetsinsatser istället för vegeterande liknöjdhet, menade Lundell att den hårda konkurrensen var nödvändig om produktionen i samhället skulle öka. Konkurrenstrycket förhindrade passivitet. Dessutom menade Lundell att det enbart var på en fri marknad som det gick att få en rättvis lönesättning, d.v.s. en avkastning på arbetet som motsvarar var och ens arbetsinsats. ${ }^{45}$ I en centraliserad och dirigerad ekonomi skulle lönen istället bli „beroende af slumpen och godtycket, enär hans lön genom maktspråk eller omröstning än skulle förhöjas och än förminskas». ${ }^{46} \mathrm{De}$

43 J. Lundell, 1846.

44 J. Lundell, 1846, s. 256.

45 J. Lundell, 1846, s. 261.

46 J. Lundell, 1846, s. 261. 
vanliga klagomålen om att en friare ekonomi medförde ökade orättvisor, och bidrog till framväxten av en våldsamt rik kategori kapitalister vid sidan av en stor massa av utarmade arbetare, avvisades av Lundell. ${ }^{47}$ Istället framhävdes ett annat utmärkande drag för den "moderna civilisationen", nämligen framväxten av en allt större medelklass. Den nya medelklassen förvärvade sig successivt ett allt större välstånd genom flit, sparsamhet och eget arbete.

Lundell menade att arbetslösheten var ett allvarligt problem, men att problemet varit än större tidigare. Han framhöll flera olika orsaker till arbetslösheten. För det första medförde regleringar av det ekonomiska livet att näringsverksamheten hämmades och att antalet arbetstillfällen blev färre. Rörligheten på arbetsmarknaden försvårades dessutom av skråregleringar av olika slag. Arbetskraft låstes in i yrken som var på tillbakagång, medan rekryteringen till expansiva yrken gick trögt. Det fanns därmed också strukturella orsaker till arbetslösheten. På vissa yrkesområden rådde det knapphet på arbetskraft, på andra överskott. De här problemen förvärrades av regleringarna, men de fanns även i den fria ekonomin. Det vore därför enligt Lundell fåfängt ratt söka bestrida det concurrensen, äfven då näringsfriheten är mest utbildad, kan tidtals blifva alltför stor i flera yrken och således medföra svåra lidanden för en stor del af den arbetande classen « ${ }^{48}$

47 Det kan vara intressant att notera att författaren bl.a. hänvisade till Engels' studie Om den arbetande klassens läge i England, utgiven 1845. J. Lundell bör därmed ha varit en av de första som uppmärksammade detta arbete i Sverige. 48. J. Lundell, 1846, s. 266.
Problemet var att de enskilda arbetarna saknade kunskaper om utbuds- och efterfrågeförhållandena på arbetsmarknaden. De hade ingen möjlighet att förutse vilka verksamheter som skulle expandera och vilka som skulle gå tillbaka. De hade naturligtvis små möjligheter att förutskicka förändringar i konsumtionsmönstret, varuefterfrågan och därmed också - indirekt - förändringar i efterfrågan på arbetskraft. Det fanns också ett konjunkturellt mönster som förvärrade situationen. ${ }^{49}$

Vilka var då botemedlen mot problemen? De botemedel som utnyttjades fick på intet sätt inskränka ekonomins och arbetets nyvunna frihet genom nya "tvångssystem". Det handlade istället om att upprätta en "förnuftig organisation för arbetets frihet". Vad Lundell syftade på - om vi använder moderna begrepp - var att förbättra arbetsmarknadens funktionssätt och reducera transaktionskostnader. Problemet var inte att antalet arbetstillfällen blivit färre - de hade tvärtom blivit fler. Det stora problemet var "svårigheten för den obildade massan att i tid uppsöka och begagna dem som finnasu. ${ }^{50}$

Ett sätt att minska arbetslösheten var följaktligen att utbilda arbetarna: "ty de lägsta yrkena, hvilka kräfva de minsta insigterna» blir lättast »öfverfyllda» och därigenom återställs »jemnvigten i den mån arbetarne förvärfva sig erforderlig bildning för att kunna

49 Enligt Lundell var "arbetaren, äfven utan sitt eget förvållande, numera blottställd för många nya faror, till följe af industriens hastiga framsteg och täta vexlingar, dem han hvarken kan förutse eller beherrska«. J. Lundell, 1846, s. 267.

50 J. Lundell, 1846, s. 269. 
välja andra sysselsättningar«. Ett annat viktigt medel mot arbetslösheten var enligt Lundell inrättandet av kommunala arbetsförmedlingar. På denna punkt var han i själva verket långt före sin tid. I riksdagen skulle denna fråga diskuteras först runt sekelskiftet efter Wavrinskys motioner om arbetsförmedlingsanstalter, den första från år 1900. Lundell hänvisade i sammanhanget till en fransk författare, De Gérando, som föreslagit matt hvarje stad skall äga en institution, som med råd och upplysningar, men icke med tvångsåtgärder och befallningar, bör ordna och leda arbetarnes anställning och fördelning inom de serskilda yrkena. Denna auctoritet bör äga en officiell karaktär och stå i samband med communalstyrelsen och fattigvården ${ }^{5 .}{ }^{51} \mathrm{Lo}-$ kala och enskilda förmedlingar för lärlingar och gesäller hade funnits tidigare. Det nya med Lundells förslag var att han såg den offentligt inrättade arbetsförmedlingen som ett medel att förbättra hela arbetsmarknadens funktionssätt.

Lundell skilde ut sig från både samtida liberaler och konservativa. Medan många liberaler under mitten av 1800-talet knappast erkände förekomsten av ett arbetslöshetsproblem i ett samhälle präglat av näringsfrihet och fri konkurrens - annat än som ett resultat av individuella ofullkomligheter eller lättja - såg Lundell arbetslöshetsproblemet klart såväl från ett konjunkturellt som ett strukturellt perspektiv. Liksom Carl Adolph Agardh menade han att näringsfrihet och ekonomisk utveckling också förutsatte någon form av sociala insatser från det offentligas sida. Men de insatser som gjordes, i form av utbildning eller ar-

51 J. Lundell, 1846, s. 270. betsförmedling, skulle förbättra snarare än försämra marknadernas funktionssätt. Till skillnad från Agardh och andra socialkonservativa hyste han inte heller några illusioner om att de gamla "husbonderelationerna" var att föredra framför de fria arbetsavtalen. Hans syn på arbetsmarknad och arbetsliv var fast förankrad i den marknadsinriktade och liberala ekonomin.

\section{Agardh och Geijer om staten och den sociala politiken}

Carl Adolph Agardh (1785-1859) var sannolikt den mest framträdande och inflytelserike representanten för den socialkonservativa idéinriktningen i Sverige. En av de mest inflytelserika debattörerna i det liberala lägret under 1840-talet var Erik Gustaf Geijer. Under 1840-41 års riksdag skulle den liberala kritiken i stor utsträckning koncentreras på just Agardh. Aftonbladet ägnade honom flera kritiska artiklar - och det var hans förslag gällande omfattande statliga investeringar i allmänna arbeten som stod i centrum för kritiken. ${ }^{52}$

När prästeståndet sammanträdde den 14 mars 1840 - drygt en vecka efter att Agardh presenterat en motion om allmänna arbeten - kom det till en ordväxling mellan Agardh och Geijer som mycket tydligt åskådliggör

52 «Är pauperismen en oundviklig följeslagare till civilisationen? En fråga i synnerhet till Biskop Agardh.«Två artiklar i Aftonbladet 18410225 och 18410226 . Dessutom kom ytterligare en artikel som var riktad mot Agardh 184103 11: „Några hufvudvilkor för ett allmännare välståndu. Alla dessa tre artiklar var mycket omfattande och hade karaktären av ideologiska programförklaringar, präglade av L. J. Hierta. 
skillnaden dem emellan. Framför allt gällde det synen på statens roll i ekonomin och vilken betydelse statliga åtgärder kan ha för att förebygga och motverka sociala missförhållanden.

Biskopen Agardh menade att fattigvården skulle vila på en grundprincip om kristlig kärlek, men ekonomen Agardh menade samtidigt att medlen och wanstalterna i fattigvårdsfrågor måste vila på samhällsekonomiska grunder. ${ }^{53}$ Agardhs huvudlinje i den sociala frågan var, som Lars Johan Hierta uttryckte det, natt det enda och rätta sättet att förekomma pauperismens alltför stora öfverhandtagande, är att staten ständigt håller ansenliga fonder disponibla för att med publika arbeten föda den der arbetslösa massan af proletärer.$^{54}$ Den motion som Agardh presenterade vid riksdagen hade i huvudsak denna innebörd. Grundproblemet var att det enskilda näringslivet och den fria marknaden aldrig skulle kunna generera tillräckligt med arbetstillfällen för att garantera inkomster åt en snabbt växande befolkning i arbetsför ålder. Den enda rimliga åtgärden från statens sida var därför, enligt Agardh, att utveckla och finansiera allmänna arbeten "hvarigenom allt det öfverskjutande antal af arbeten, som ej kunna finna sysselsättning genom den långsamma utvidgningen af den enskilda industrien $i$ Sverige, måtte kunna finna arbete och underhållk...5 Detta var den renodlat sociala

53 1840-41 års riksdag, Prästerskapets protokoll, 1, s. 322.

54 «Är pauperismen en oundviklig följeslagare till civilisationen? En fråga i synnerhet till Biskop Agardh."Aftonbladet 18410225.

55 1840-41 års riksdag, Prästerskapets protokoll, 1, s. 328. synpunkten. Sedan menade Agardh dessutom att investeringar i allmänna arbeten med inriktning på infrastrukturen, skulle ge dynamiska effekter, som direkt skulle befrämja enskilt företagande, och därmed indirekt också den framtida sysselsättningen.

Erik Gustaf Geijer hade visserligen inga invändningar mot Agardhs förslag om förbättringar av kommunikationsnätet. Men han hade en helt annan uppfattning om orsakerna till fattigdomen, och om möjligheterna att via en statlig politik och statlig sysselsättning förbättra situationen för de fattiga. Geijer gjorde en kärvare tolkning av relationen mellan befolkningens storlek och näringslivets utveckling, d.v.s. efterfrågan på arbetskraft. Enligt Geijer var "folkökningens ostridiga tendens att öfverskrida de för handvarande subsistensmedlen just ett medel i försynens plan, att drifva menniskorna, vore det ock med nöden till läromestare, allt längre fram på odlingens bana». ${ }^{56}$ Fick bara människorna möjligheter att utveckla sin "individuella frihet « skulle de inte låta sig hindras av några svårigheter. Det viktiga var att alla krafter inriktades på att avskaffa de regleringar som förhindrade individernas möjligheter att förbättra sin försörjningssituation.

Geijer menade att Agardhs program för allmänna arbeten skulle medföra flera hinder än fördelar för ekonomins utveckling. Statens roll och inflytande i ekonomin borde hållas vid ett minimum. Geijer förespråkade i det närmaste nattväktarstaten; en stat som enbart utfäster sig att garantera rättstrygghet och egendomsrätt. För Sveri-

56 1840-41 års riksdag, Prästerskapets protokoll, 1, s. 331 . 
ges del var det dock, enligt Geijer, nödvändigt med statliga undsättningsanstalter i form av nödhjälpsarbeten. Men det var snarare klimatologiska än sociala förhållanden som fick Geijer att förespråka dessa inrättningar, närmare bestämt de många sfrostnätterna« och deras destruktiva inverkan på jordbruket. Nödhjälpsarbetena skulle organiseras i mycket begränsad omfattning och sättas in när nöden så krävde, i huvudsak vid missväxter. Geijer avvisade således Agardhs förslag om permanenta statliga arbeten. Han hade en mycket starkare tilltro till den fria ekonomins förmåga att på lite sikt - bara inte friheten kringskars - garantera den trygghet och skapa de resurser som Agardh försökte åstadkomma på konstlad väg genom statliga ingrepp.

Agardh hade en annan uppfattning om statens möjligheter att minimera sociala missförhållanden och påverka resursutnyttjande och sysselsättningsnivåer i samhället: „För min del kan jag icke medgifva min värde motståndares sats, att Staten bör inskränka sig till den negativa åtgärden att lemna allt fritt åt den enskilda omtankan och fliten; jag tror, att Staten äfven åligger positiva åtgärder, genom öppnandet af nya inkomstkällor, och af tillfällen till ny arbetsförtjenst/.../så snart nemligen företagen äro för vidsträckta att af enskilda företagas «. ${ }^{57}$ Agardh menade inte att staten skulle ge sig in på direkt konkurrens med privata företag. Däremot ansåg han att man inte kunde förvänta sig att enskilda företag eller individer skulle våga investera i större samhällsnyttiga projekt, som kostnadstunga och

57 1840-41 års riksdag. Prästerskapets protokoll, 1, s. 333. långsiktiga investeringar i kanaler, vägar och järnvägar.

\section{Sammanfattning och slutsatser}

Befolkningsökningen, den sociala differentieringen och de utvidgade marknadsrelationerna i ekonomin bildade bakgrund till den intensiva debatten i sociala frågor vid 1800-talets mitt. Samhällsomvandlingen i marknadsekonomisk riktning tvingade fram nya politiska perspektiv. Frågorna om fattigdom och arbetslöshet formulerades på ett nytt sätt. Fattigdom och arbetslöshet uppfattades som samhälleliga problem. De enskilda individerna skuldbelades inte längre. Istället framhölls näringarnas bristfälliga utveckling, handelshinder och missväxter som huvudorsaker till återkommande nöd och arbetslöshet. Konsekvensen av denna "rehabilitering « av de fattiga blev att de offentliga institutionerna - sockenkommunerna och staten - utkrävdes ett större ansvar för att motverka sociala missförhållanden.

Men även om fattigdom och arbetslöshet uppfattades som samhälleliga problem, rådde oenighet om statens och kommunernas möjligheter att påverka de sociala villkoren. Skiljelinjen gick i huvudsak mellan liberalernas tilltro till näringsfrihetens och marknadernas förmåga att läka sociala sår, och de socialkonservativas förtröstan på politiska ingrepp i ekonomin. För socialkonservativa som Carl Adolph Agardh betydde den oinskränkta "fria ekonomin» kaos och styggelse. En positiv utveckling av det ekonomiska och sociala livet var otänkbar om inte staten satt vid rodret. Det betydde nu inte att man nödvändigtvis behövde förespråka en åter- 
gång till gamla näringsregleringar. Däremot betydde det att man uteslöt möjligheten av en positiv utveckling om inte den fria marknadens spel parerades med statliga investeringar och offentliga sociala insatser. Motsättningen mellan den ekonomiska liberalismens obändiga tro på individernas skapande förmåga och socialkonservativa och socialistiska gruppers krav på offentliga insatser, präglade hela 1800-talets socialpolitiska och arbetslöshetspolitiska debatt.

Vid mitten av 1800-talet fanns det en politisk övervikt för den mer expansionistiska och statsinterventionistiska synen på sociala och ekonomiska frågor, enligt Agardhs modell. Denna syn präglade också besluten om allmänna arbeten, om statliga nödhjälpsarbeten och bidrag till missväxtdrabbade bygder samt de nya fattigvårdsförordningarna 1847 och 1853. Detta kan delvis förkla- ras av det dåtida politiska representationssystemet, men i huvudsak av att 1800-talets mitt var en period präglad av intensiv omvandling och kraftigt befolkningstryck. Det krävdes ett ökat mått av offentlig intervention i ekonomin för att underlätta omställningen till nya förhållanden, bl.a. till en mer marknadsinriktad ekonomi; till ett ökat lönearbetsberoende samt en ökad sårbarhet vid kriser - om än fortfarande inom landsbygdslivets ram.

Huvudlinjerna i 1830- och 40-talens debatter går igen $i$ vår tids diskussioner om den offentliga sektorn. Frågan om det går att göra stora statliga ingrepp för att påverka inkomstfördelning och resursutnyttjande utan att försämra - eller t.o.m. att förstöra - drivkrafterna för uthållig ekonomisk tillväxt kvarstår. Svaren har skiftat över tiden.

\section{Referenser}

1840-41 års riksdag. Prästerskapets protokoll

Aftonbladet 1841

Bastiat, F (1954) Hvad man ser og hvad man ikke ser. Aktuelle almenfattelige erhvervsekonomiskabetragningar, Köpenhamn

Berge, A (1995) "Socialpolitik och normgivning $i$ Sverige 1871-1913", Arkiv för studier i arbetarrörelsens historia, nr 63-64

Bergman, C W (1848) Den sociala frågan, Stockholm

Borgström, G(1969) Malthus. Om befolkningsfrägan, Halmstad

Derry, T K \& Jarman, T L (1970) The Making of Modern Britain, Norwich

Ekenstam, E (1847) „Om de väsendtligaste orsakerna till Svenska Landtbrukets tilltagande obestånd, samt om det viktigaste medlet för dess återhjelpande", Odalmannen, nr 3

Foucault, M (1968) Vansinnets historia under den klassiska epoken, Malmö
Gasslander, S O (1949) J A Gripenstedt, Lund

Handlingar från 1837 års fattigvårdskommitté, Riksarkivet, Stockholm

Heckscher, E (1963) Svenskt arbete och liv, Stockholm

Hultgren, O J (1855) Ompauperismen. Bidrag till Sveriges fattigvårds-lagstiftnings historia, Stockholm

Johansen, H C (1968) Dansk ekonomisk politik i arrene efter 1784, Aarhus

Karlbom, R (1967) Hungerupplopp och strejker 1793-1867. En studie i den svenska arbetarrörelsens uppkomst, Göteborg

King, S (1997) „Poor relief and English economic development reappraised“, Economic History Review, nr 2

Kjellén, A (1933) „Geijer och fattigdomsproblemet", Historisk tidskrift

Klinckowström, R M (1867) Jordbrukets Nöd och hjelp, Stockholm 
Kumm, E(1940) Nödärsbygd och samhällshjälp, Stockholm

Landquist, J (utg) (1928) Geijers samlade skrifter, Stockholm

Lestadius, P (1840) Tankar om fattigdomen och fattigvairden i Sverige, Stockholm

Lundell, J (1846) Om handtverksskrån. Näringsfrihet och Arbetets Organisation, Lund

Montgomery, A (1934) Svensk socialpolitik under 1800-talet, Stockholm

Nilsson, G B (1965) "Svensk fattigvårdslagstiftning 1853-1871 «, i Liberal socialpolitik
1853-1884. Två studier, Uppsala

Polanyi, K (1990) Den stora utmaningen, Lund

Seip, A-L (1984) Sosialhjelpsstaten blir til. Norsk Sosialpolitikk 1740-1920, Oslo

Solar, P M (1997) „Poor relief and English economic development", Economic History Review, $\mathrm{nr} 2$

Utterström, G(1957) Jordbrukets arbetare, del 1 och 2, Stockholm

Wallentin, H(1987) Kring arbetslöshets- och socialpolitik i Sverige sedan 1700-talet, Östersund

\section{Summary \\ Ideas about unemployment and social policy in the mid-nineteenth century}

Labour market policy has been in the forefront of the economic-political debate in Sweden during the post-war period. Much research has been devoted to the development of the labour market policy and its historical roots. The time perspective, however, has often been narrow, very seldom integrating the period before the first two decades of the twentieth century. This article emphasizes the importance of nineteenthcentury political and social developments for the breakthrough of modern labour market policy.

During the rapid social and economic changes in the nineteenth century, unemployment became a social threat and relief measures for the unemployed an important task. This can be explained by the midnineteenth-century liberal breakthrough in Swedish politics, and the development reflected the structural transformation of the society at that time. The changes in the agricultural sector, social differentiation, and rapid population growth demanded a more flexible labour market. Policies changed and mercantilist restraints were abolished. The appearance of free market structures and wage-dependent groups gave new meaning to the word "unemployment" and the social problems associated with the unemployment question. In the tension emanating from the conflicts between a regulated and a market economy, between a society based on the Estates and one based on class, and between conservatism and liberalism, the first steps were taken towards an unemployment policy.

Concern over the growth of a poor and non-propertied class marked the debate on poor relief in which the problems of "involuntary unemployment" were ventilated for the first time. The report submitted in 1839 by the poor relief commission appointed two years earlier, as well as the poor relief statutes promulgated in 1847 and 1853 , not only recognized the existance of involuntary unemployment. They also declared that society had an obligation to alleviate the plight of the unemployed in the form of work relief schemes or public works projects. 